\title{
The Washback Effects of English National Examination in Teaching and Learning English for Deaf Students
}

\author{
Najmi Hilalliyati ${ }^{1}$,Fahriany ${ }^{2}$ \\ \{najmi@uinjkt.ac.id ${ }^{1}$, fahriany@uinjkt.ac.id ${ }^{2}$ \} \\ UIN Syarif Hidayatullah Jakarta ,Indonesia ${ }^{1,2}$
}

\begin{abstract}
This study aimed to see the teacher's perspective and the positive or negative washback effect about English National Examination in teaching and learning English for deaf students at the tenth grade of SMALB Negeri 01 Lebak Bulus Jakarta Selatan. Qualitative-descriptive was used as a method in this study. The Instruments used in this study were observation guideline, interview guideline and documentations. Techniques of collecting data were used in this study namely observation, interview, and documentation such as photo camera, video recorder, syllabus and lesson plan. The results of this study showed that (1) the main problem to implement the National Examination was the deaf students difficulty to understand and comprehend the questions in English subject (2) there were positive and negative wash back of English National Examinations in teaching and learning for deaf students.
\end{abstract}

Keywords:Washback, English National Examination, Deaf Students.

\section{Introduction}

National Examination is compulsory test to determine whether a student can graduate from a primary and secondary level of education, or should repeat [1]. Since its first implementation in 1965, a steady debate over National Examination practice in Indonesia continues, mainly on the format, effectiveness, and effects of national exam. Government believes that establishing national examinations will push teachers to teach better and students to learn more [2]. However, critics argue that such exam is not beneficial since this examination cannot guarantee the improvement of teacher instruction and student motivation.

Nevertheless, both the pros and cons base their arguments on common sense not supported by a sound reasoning. This study tries to discover the washback effects of English National Examination (ENE) in Indonesian Senior High School education. In this study, the writers tries to find out about teachers' perceptions in SMALB Negeri 01 Lebak Bulus to analyze on deaf students` National Examination achievement. The dimensions of the washback effect of ENE on English teachers are negative and positive, strong, specific and for a short period time.

As pros and cons concerning the National Examination are getting more intense, this study tries to explore the washback effects caused by the NE in Indonesia, including whether the washback is positive or negative, the areas of washback, and its dimensions seen from teacher perspectives in teaching and learning for deaf students.

Cheng and Watanabe defined washback or backwash here discusses to the impact of testing on teaching and learning [3]. The concept is fixed in the notion that tests or examinations can and should determination teaching, and hence learning, and it also stated to as measurement-driven instruction. The reason of this goal being successful is a "match" or the connection between the content and format of the test or the examination and the content and format of the curriculum (or "curriculum surrogate" such as the textbook) is motivated. This is discussed to as curriculum alignment by Shepard. Even though the idea of association-matching the test and the curriculum - has been defined by some as "unethical," and terrifying the validity of the test, such arrangement is evident in a number of countries, for example, Hong Kong. This arrangement, in which a new or reviewed examination is offered into the education system with the purpose of 
enlightening teaching and learning, is stated to as systemic validity by Frederiksen and Collins, consequential validity by Messick and test impact by Bachman and Palmer and Baker [4].

The study of washback has led to in latest rises in language testing, and measurement-driven transformation of instruction in general education [5]. Research in language testing has focused on whether and how to size the specific characteristics of a detailed group of test takers and whether and how to contribute such information into the ways in which we enterprise language tests. One of the most significant theoretical progresses in language testing in the past 30 years has been the consciousness that a language test score indicates a complex of multiple influences [6]. Language test scores cannot be interpreted simplistically as an indicator of the particular language capability we think we are determining. The scores are also affected by the characteristics and contents of the test tasks, the characteristics of the test takers, the strategies test takers employ in struggling to complete the test tasks, as well as the implications we attraction from the test results. These factors certainly interact with each other.

Some researchers defined that positive washback discusses to tests or examinations that impact teaching and learning beneficially when testing technique encourages 'good' teaching practices. In this sense, teachers and students have a positive attitude towards the test and work enthusiastically towards its objectives. Furthermore, Brown stated that a test's washback effect will be negative if it fails to expose the learning principles and course objectives to which the test deceptively relates, and it will be positive if the effects are useful and stimulate the whole range of desired changes [7].

\section{Research Methods}

In conducting this study, the writers use qualitative method. The research method used in this study is qualitative-descriptive. Qualitative research is a kind of educational research in which the writers relies on the views of participants; asks broad, general questions; collect data consisting largely of words (or text) from participants; describes and analyzes these words for themes; conducts the inquiry in a subjective, biased manner[8]. Meanwhile descriptive research design is a scientific method which includes observing and describing the behavior of a subject without controlling it in any way.

The data were collected through observation and interview. In observation, the writers observed about three times at SMALB Negeri 01 Lebak Bulus. The first time, the writers surveyed the school and interviewed the headmaster about the school. Based on the interview with her, the writers increased some useful information regarding with deaf students principally and inclusive school, she also described several classification in inclusive school. The second time, the writers, interviewed the English teacher of SMALB Negeri 01 Lebak Bulus about English curriculum that used in the school, about English National Examination was held in SMALB Negeri 01 Lebak Bulus and planed about observation in the class with the deaf students. The last time, the writers observed the deaf students of SMALB Negeri 01 Lebak Bulus in teaching and learning English.

For interview section, the writers interviewed the headmaster and the English teacher of SMALB Negeri 01 Lebak Bulus, even the writers tried to interview the deaf students using the sign.

The data analysis includes these following points. First, contextual information about SMALB Negeri 01 Lebak Bulus which include into inclusive schools, characters for deaf students, teaching and learning process for deaf students and facility that available for deaf students in teaching and learning process. And the last, the documents such as English Curriculum for deaf students and sample of English National Examination for deaf students.

\section{Result and Discussion}

\section{A. Result}

The discussion are the answers for the research questions which have been mentioned above, what do the teachers think or argue about English National Examination washback effect in teaching and learning for deaf students and what are positive or negative washback of English National Examinations in teaching and learning for deaf students. 


\section{The result of observation}

In observation, the writers observed about three times at SMALB Negeri 01 Lebak Bulus. The first time, the writers surveyed the school and interviewed the headmaster about the school. Based on the interview with her, the writers enlarged some beneficial information regarding with deaf students particularly and inclusive school, she also explained several classification in inclusive school.

The second time, the writers, interviewed the English teacher of SMALB Negeri 01 Lebak Bulus namely Mr. Rambat, S.Pd about how English National Examination was held at SMALB Negeri 01 Lebak Bulus and how the process of English National Examination for deaf students. Based on the explanation from the English teacher, the deaf students of SMALB Negeri 01 Lebak Bulus conducted English National Examination just like other students in the regular schools.

The last time, the writers observed the tenth grade deaf students of SMALB Negeri 01 Lebak Bulus. The writers observed about English teaching and learning in the classroom at the tenth grade deaf students. In this section, English teacher taught about how to write letter to friends. The teacher begun the activities with wrote down the example of letter in whiteboard and the deaf students copied the text to their book. Then, the teacher started to read the text using the sign and translated the text word by word using the sign. The teacher also instructed the deaf students to answer the question based on the text that adopted form the book.

\section{The result of interview}

For interview section, the writers interviewed the headmaster and the English teacher of SMALB Negeri 01 Lebak Bulus, even the writers tried to interview the deaf students using the sign.

Based on the interview with the headmaster, the writers increased some useful information regarding with deaf students particularly and inclusive school, she also explained several classification in inclusive school and characteristics of students with special needs.

The writers interviewed the English teacher about about how English National Examination was held at SMALB Negeri 01 Lebak Bulus, how the process of English National Examination for deaf students and there are any effects for deaf students in English teaching and learning process. Based on the explanation from the English teacher, the deaf students of SMALB Negeri 01 Lebak Bulus conducted English National Examination just like other students in the regular schools. Furthermore, the English teacher also explains that deaf students have several difficulties in conducted English National Examination. He explains that for several times he should explains briefly about the instructions in the English National Examination and translate the questions word by words in order deaf students understand the instructions.

\section{B. Discussion}

In this part, the writers will describe about the result of the research. The writers will interpret two parts based on research questions in the first chapter.

1. What do the teachers think or argue about English National Examination washback effect in teaching and learning for deaf students?

As the result of interview from the English teacher namely Mr. Rambat, S.Pd, English subject is one of the subjects that should be examine in the National Examination for deaf students in Indonesia. He explained that the difficulty in communicating using sign language is main constrain in the application of the National Examination for deaf students at SMALB Negeri 01 Lebak Bulus. That also the problem for SMALB Negeri 01 Lebak Bulus to exchanged the teacher with hither teachers of Santi Rama School for disable students who also handle the deaf students. According to Mr. Rambat, besides communication problem, the students also need the pictorial exam questions. The type of deaf students` examination question should be simple and consisting of pictures.

Furthermore, the English teacher enlarged that there are positive and negative effect of English National Examination for deaf students for sure. In general, washback effect of English National Examination in teaching and learning for deaf students are the English teacher more concentrated to teach material that predicted in next English National Examination and just focused to discuss 
about English National Examination questions before[9]. The other effect is the Headmaster more considered about the parents` perception about SMALB Negeri 01 Lebak Bulus accreditation based on the graduates from this school.

In this case, there is misrepresentative in the determination of English National Examination for deaf students. Based on description in the previous explanation that washback effect states to the impact that tests have on teaching and learning [10]. Additionally, there is several washback effect of English National Examination for deaf students of SMALB Negeri 01 Lebak Bulus.

2. What are positive or negative washback of English National Examinations in teaching and learning for deaf students?

Based on the English teacher explanation, there are positive and negative washback of English National Examination in teaching and learning for deaf students, they are:

a. Positive washbak effect:

a) English National Examination could be the tool for an Evaluation for the English teacher

b) Various aspects of the students' learning in School, such as: the students are totally organizing for English National Examination since the $2^{\text {nd }}$ semester of the twelfth grade. English National Examination has affected the material taught by the teachers principally when they have English National Examination try out.

b. Negative washbak effect:

a) Based on teaching materials there are more reading exercises, textbooks, text types (genre), complementary materials from the Internet and newspapers, English National Examination past papers, commercial books for English National Examination preparation.

b) Based on the teaching strategies more exercise on English National Examination format.

c) Nervous, stressful, pressure for the deaf students.

\section{Conclusion}

The conclusion is completed based on the explanation given to answer the research question. First, what do the teachers think or argue about English National Examination washback effect in teaching and learning for deaf students. The difficulty in communicating using sign language is main constrain in the implementation of the National Examination for deaf students at SMALB Negeri 01 Lebak Bulus and the type of deaf students` examination question should be simple and consisting of pictures.

And the last, what are positive or negative washback of English National Examinations in teaching and learning for deaf students. The positive washback effects are: English National Examination could be the tool for an Evaluation for the English teacher and some aspects of the students' learning in School, such as: the students are completely preparing for English National Examination since the $2^{\text {nd }}$ semester of the twelfth grade. English National Examination has affected the material taught by the teachers particularly when they have English National Examination try out. Negative wash back effect could be classified based on teaching materials, teaching strategies and deaf students`attitude.

\section{References}

[1] The Government of Indonesia Republic, (2003). Undang-Undang No. 20 Tahun 2003 tentang Sistem Pendidikan Nasional. Jakarta: The Government of Indonesia Republic.

[2] Sulistyo, G. H. (2009). English as a measurement standard in the national examination: Some grassroots' voice. TEFLIN journal. 20(1), pp.1 -23.

[3] Cheng, L. and Watanabe, Y. (2004). Washback in Language Testing Research Contexts and Methods. New Jersey: Lawrence Erlbaum Associates, Inc.

[4] Bachman, L. and A. Palmer. (1996). Language Testing in Practice. Oxford: Oxford University Press. 
[5] Alderson, C. J. and Wall, D. (1993). Does Washback Exist? Applied Linguistics, Vol, 14 No. 2. Oxford University Press.

[6] Bachman, L. (1990). Fundamental Considerations in Language Testing. Oxford: Oxford University Press.

[7] Brown, D. H. (2004). Language Assessment Principles and Classroom Practices. Longman: Pearson Education, Inc.

[8] Creswell, J. W. (2012). Planning, Conducting, and Evaluating Quantitative and Qualitative Research (4th edition). Boston: Pearson Education, Inc.

[9] Rose, Susan. (1998). Assessment of Students who are Deaf and Hard of Hearing. Faribault: Minnesota Resource.

[10] Paul, Peter V. (2009). Language and Deafness. Canada: Jones and Bartlett Publisher. 